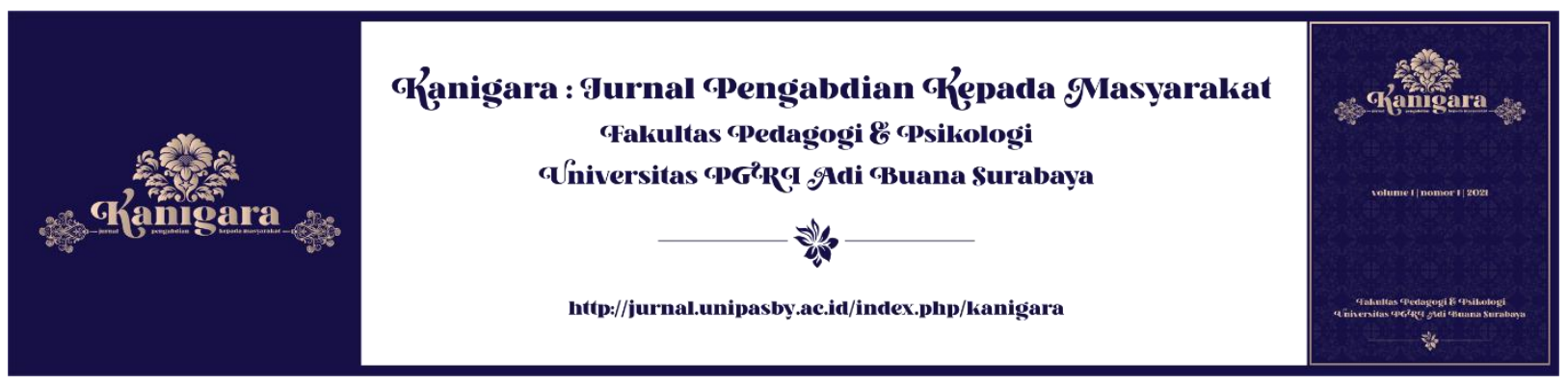

\title{
Pelatihan Batik Tulis Dengan Media Pewarna Naptol Garam Bagi Siswa Panti Asuhan Yayasan Muslim Surabaya
}

\author{
Tantra Sakre', Sepbianti Rangga Patriani' ${ }^{2}$, Herman Sugianto ${ }^{3}$ \\ 1,2,3Universitas PGRI Adi Buana Surabaya \\ Email: tantrasakre@unipasby.ac.id
}

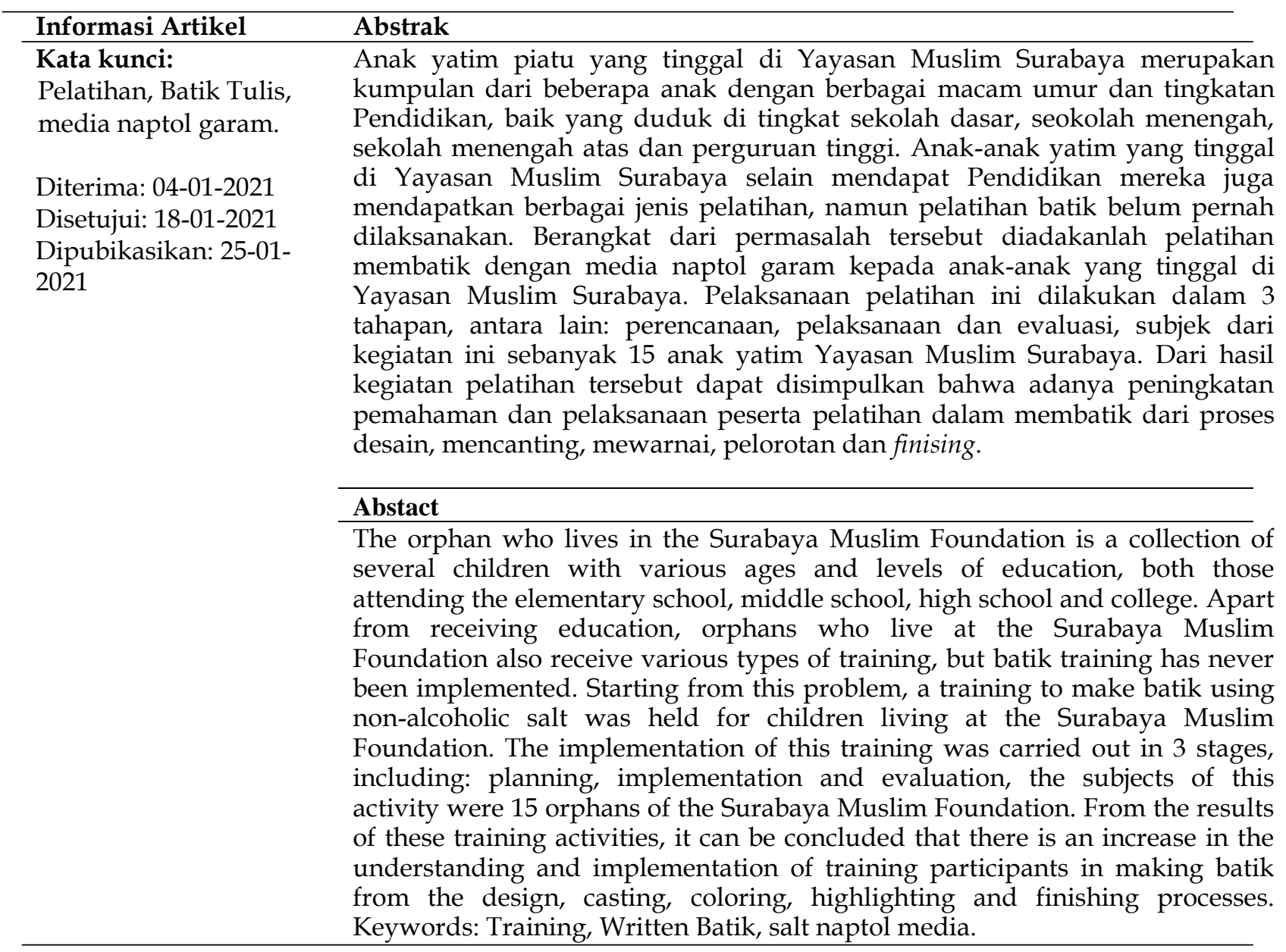


Pelatihan Batik Tulis Dengan Media Pewarna Naptol Garam

Bagi Siswa Panti Asuhan Yayasan Muslim Surabaya

\section{LATAR BELAKANG}

Dalam pelaksanaan pemenuhan kewajiban negara kepada rakyat maka ditetapkanlah Undang-undang, Peraturan Pemerintah, Peraturan Daerah serta peraturan lain yang bersifat mengikat dengan berkiblat kepada batang tubuh negara Indonesia yaitu Pancasila dan UUD 1945. Salah satu langkah komprehensif yang dilakukan oleh Negara dalam memberikan kesejahteraan dan kemakmuran secara merata kepada masyarakat Indonesia tertuang dalam UU No. 23 tahun 2014 tentang pemerintahan daerah (merupakan revisi dari UU No. 32 Tahun 2004 yang didasarkan pada Tap. MPR RI No. IV/MPR/2000; Tap. MPR RI No. XV/MPR/1998; UUD RI 1945 Pasal 18 ayat 1-7, Pasal 18A ayat 1 dan 2, Pasal 18B ayat 1 dan 2). Dalam UU 23 tahun 2014 terangkum hak-hak khusus yang diberikan oleh negara baik itu bersifat Desentralisasi, Dekonsentrasi maupun tugas pembantuan dalam pelaksanaan pemerintahan dan rumah tangga daerah terkait yang mengedepankan unsur kemandirian (Trisnawati, Wahyono, \& Wardoyo, 2018).

Yayasan Muslim memiliki tiga fasilitas yaitu Panti Asuhan Muslim Surabaya, KB-TK Muslim Surabaya dan TPQ (Taman Pendidikan Al-Quran), dimana masing-masing fasilitas memiliki struktur organisasi sendiri, namun masih dalam satu Yayasan yakni Yayasan Muslim Surabaya. Yayasan Panti Asuhan Muslim Surabaya memiliki 50 anak asuh yang terdiri dari 40 laki-laki dan 10 perempuan dengan jenjang Pendidikan yang berbeda-beda, dari tingkat dasar sampai tingkat perguruan tinggi. Anak-anak di Yayasan Muslim Surabaya dibekali dengan berbagai keterampilan yang akan mendukung skil mereka untuk siap disaat terjun di masyarakat, diantara pelatihan yang sudah dilakukan yaitu, pelatihan berpidato dan pelatihan memasak. Dari pelatihan keterampilan yang pernah dilakukan masih belum cukup untuk dijadikan bekal untuk terjun d masyakat. Salah satu solusi yaitu memberikan Pelatihan membatik dari proses desain sampai proses finishingnya. Membatik merupakan Potensi lain yang dimiliki tetapi belum dimaksimalkan hingga saat ini yang merupakan potensi akan kekayaan budaya lokal. Terlebih lagi dunia sudah mengakui keberadaan batik sebagai salah satu warisan dunia yang berasal dari Indonesia yang harus dilestarikan (UNESCO, 2009). Fungsi utama batik sebagai sebuah pakaian suatu daerah terutamanya di daerah pesisir maupun pakaian nasional, kini sudah mulai berkembang di era saat ini. Batik dengan motif tertentu bisa menjadi salah satu suvenir khas yang bisa terkenal ke manca negara (Darnawi, 2011).

Produk Batik yang semakin disukai oleh masyarakat luas akan berimbas langsung dengan banyaknya kebutuhan akan tenaga kerja sehingga ikut berdampak akan adanya lapangan pekerjaan dan menambah pemasukan. Menurut Rindia (2009), batik yang 
merupakan hasil gambar yang dihasilkan dengan alat canting dengan bahan lilin sebagai penahan masuknya warna berkembang tidak semata-mata untuk kepentingan busana tetapi dapat digunakan untuk elemen interior, cenderamata bahkan barang-barang mebel. Sehingga produk Batik mempunyai banyak potensi untuk dikembangkan di masa yang akan datang.

Berdasakan latar belakang diatas pelatihan batik tulis untuk anak-anak yatim di Yayasan Muslim Surabaya sangat perlu dilakukan guna menambah bekal keterampilan yang akan mereka terapkan nanti setalah terjun dimasyarakat, baik sebagai pengrajin batik, disainer batik ataupun sebagai pedagang batik.

\section{METODE PELAKSANAAN}

Pelatihan batik tulis dengan media naptol garam yang dilaksanakan di panti asuhan Yayasan Muslim Surabaya ini adalah sebuah bentuk program pengabdian masyarakat yang dilakukan guna mediseminasikan dan mentransfer ilmu kepada masyarakat dalam hal ini anak-anak panti asuhan yang sangat butuh sekali untuk bekal mereka nanti setelah keluar dari panti asuhan. Pada pelaksaan di lapangan, program ini terbagi menjadi 3 bagian: tahapan Perencanaan, Pelaksanaan, dan Evaluasi.

\section{PERENCANAAN}

Pada tahap perencanaan, tim melakukan wawancara, observasi dan dokumentasi pada anak-anak di panti asuhan Yayasan Muslim Surabaya. Tahapan wawancara, observasi dan dokumentasi ini dilaksanakan satu hari sebelum pelaksanaan pelatihan yaitu pada tanggal 22 Desember 2020. Observasi dan wawancara dilakukan guna mengetahui permasalahan yang dihadapi oleh teman-teman panti asuhan Yayasan Muslim Surabaya. Sebaga narasumber yang diwawancarai salah satunya pengurus panti asuhan yaitu bapak agus yang beliaunya sebagai penanggung jawab bidang minat dan bakat anak-anak panti asuhan. Dengan melaksanakan wawancara yang baik maka kesalahan di dalam pengumpulan data dapat ditekan serendah mungkin (Soegijono \& KR, 1993). Berangkat dari hasil observasi dan wawancara tersebut tim merumuskan metode pelatihan yang hendak diberikan kepada anak-anak panti asuhan. Setelah itu dibentuklah modul-modul pelatihan yang akan digunakan ketika pelaksanaan pelatihan. 


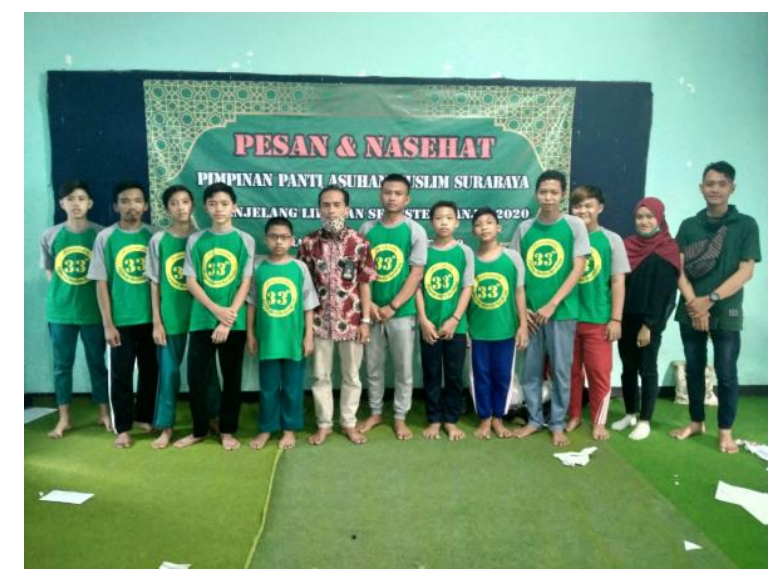

Gambar 1. Peserta pelatihan, sumber: (foto pribadi, 2020)

Dari hasil analisis wawancara terhadap objek pengabdian, dirumuskan sebuah metode pelatihan serta modul yang sesuai dengan permasalahan yang aktual terjadi di lapangan.

Dari hasil wawancara, didapatkan bahwa anak-anak panti asuhan Yayasan Muslim Surabaya masih banyak membutuhkan pelatihan-pelatihan yang tepat guna, salah satu bentuk pelatihan yang diharapkan yaitu pelatihan batik tulis dari proses awal sampai akhir.

Tim peneliti merumuskan beberapa pelatihan yang akan diberikan kepada anakanak panti asuhan Yayasan Muslim Surabaya dan dikawin silangkan dengan kompetensi masing-masing dosen yang ikut berpartisipasi dalam pelatihan ini.

\section{PELAKSANAAN}

Pada tahapan ini, modul-modul pelatihan yang telah dirumuskan sebelumnya diajarkan pada Karang Taruna Desa Begaganlimo. Suatu model pelatihan dianggap efektif manakala mampu dilandasi kurikulum, pendekatan dan strategi yang sesuai dengan kebutuhan belajar sasaran didik dan permasalahan- permasalahan yang terjadi di tengah-tengah nya (Kamil, 2003).

Pada hari pertama pelatihan yaitu dilaksanakan pada tanggal 23 Desember 2020, pelaksanaan berjalan lancar, semua peralatan membatik dan perlengkapan membatik yang telah dipersiapkan sebelumnya dibawa menuju lokasi pelatihan. Peserta pelatihan yaitu anak-anak panti asuhan datang keruang aula pelatihan dan mereka mengisi absen. Pada pelatihan di hari pertama terdapat tiga kegiatan, yakni pengenalan bahan, pembuatan desain dan proses pengemalan (pemindahan desain dari kertas ke kain). Pelatihan pertama yaitu pengenalan bahan, peserta mendapatkan wawasan tentang bahan-bahan yang digunakan dalam batik tulis, mereka dapat mengetahui jenis-jenis 
Pelatihan Batik Tulis Dengan Media Pewarna Naptol Garam

Bagi Siswa Panti Asuhan Yayasan Muslim Surabaya

kain, jenis malam, jenis pewarna, jenis canting, jenis kompor dan peralatan pendukung didalam membatik. Pada tahapan pertama berjalan dengan lancer, semua peserta dapat memahami dengan baik.

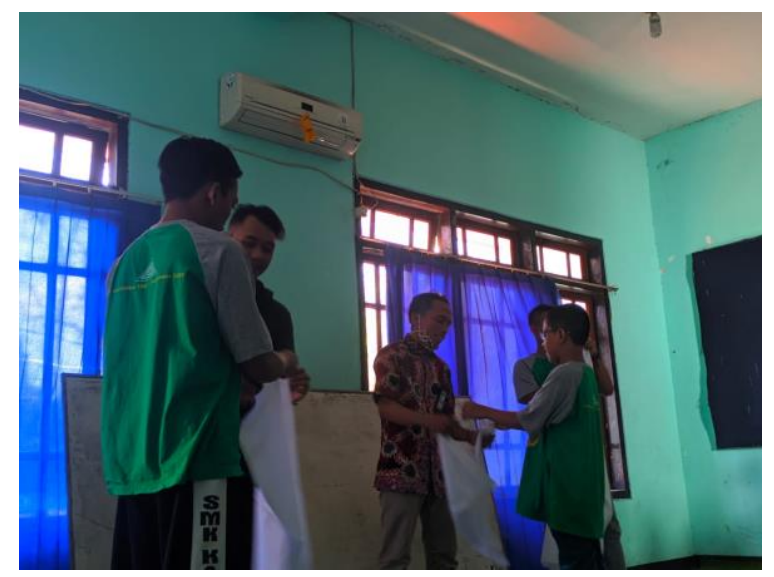

Gambar 2. Pengenalan bahan kain batik, sumber: (foto pribadi, 2020)

Tahap kedua yaitu pembuatan desain motif batik yang akan diaplikasikan mengangkat tema ikon dari Yayasan muslim Surabaya. Pada tahapan ini peserta pelatihan mendapatkan cara membuat desain batik yang baik dan benar, dari menentukan tema atau motif yang akan diangkat sampai dengan mengkombinasikan dengan motif-motif lain, sehingga menjadi sebuah motif yang baik dan bernilai jual. Pada tahapan ini berjalan dengan lancar semua peserta dapat memahami dan menerapkan.

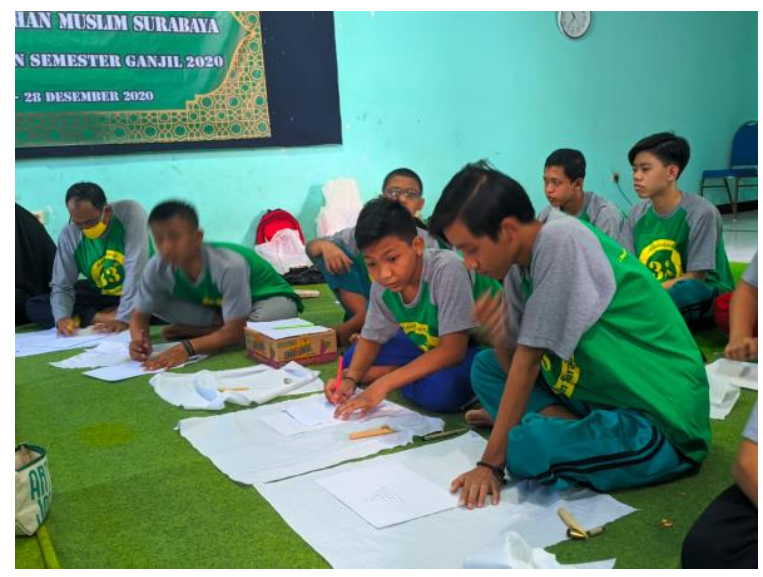

Gambar 3. Proses pembuatan desain pada kertas, sumber (foto pribadi, 2020)

Tahapan ketiga yaitu pengemalan (pemindahan desain dari kertas ke media kain), pada tahapan ini peserta melakukan kegiatan memindahi desain yang sudah dibuat kedalam kain yang berukuran 50x50 degan menggunakan pensil. Pada tahapan ini peserta dapat memahami dan melaksakan dengan baik dan benar. 
Pelatihan Batik Tulis Dengan Media Pewarna Naptol Garam

Bagi Siswa Panti Asuhan Yayasan Muslim Surabaya

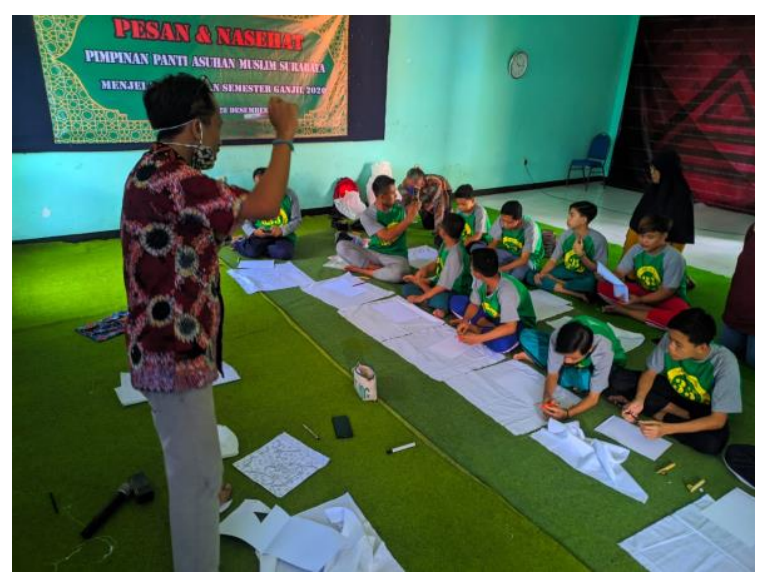

Gambar 4. Proses jiplak, sumber:(foto koleksi pribadi, 2020)

Pada hari kedua pelatihan batik tulis dilaksakan pada tanggal 24 Desember 2020 yang terdapat tiga tahapan yaitu: tahapan pencatingan, pewarnaan dan pelorotan. Tahapan pertama yaitu pencantingan, peserta melakukan pencantingan dengan menggunakan media canting, malam dan kompor lestrik. Peserta mencanting diatas kain yang sebelumnya sudah didesain sesuai dengan motif yang akan digunkan dan kain sudah melalui proses pengolahan yaitu perendaman dengan larutan TRO selama 24 jam dengan tujuan untuk menghilangkan kandungan kanji pada kain yang baru dari pabrik. Pada tahapan ini berjalan dengan lancar walaupun hasil yang didapat belum mencapai tingkat yang baik, karena hal ini butuh waktu yang lama untuk proses menjadi bagus.

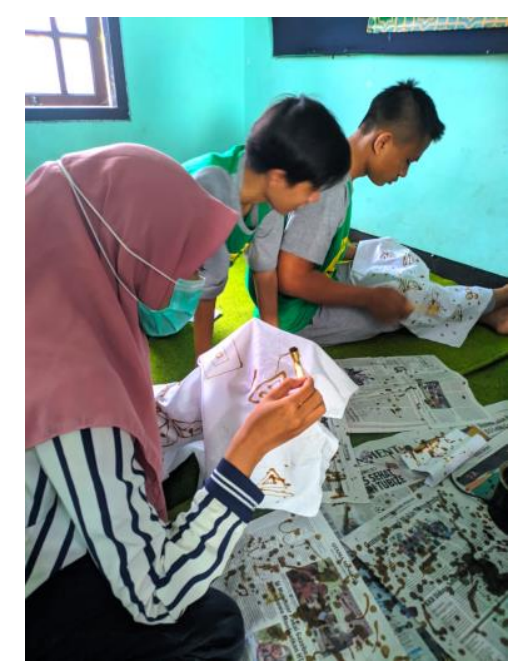

Gambar 5. Proses pencantingan, sumber (foto pribadi 2020) 


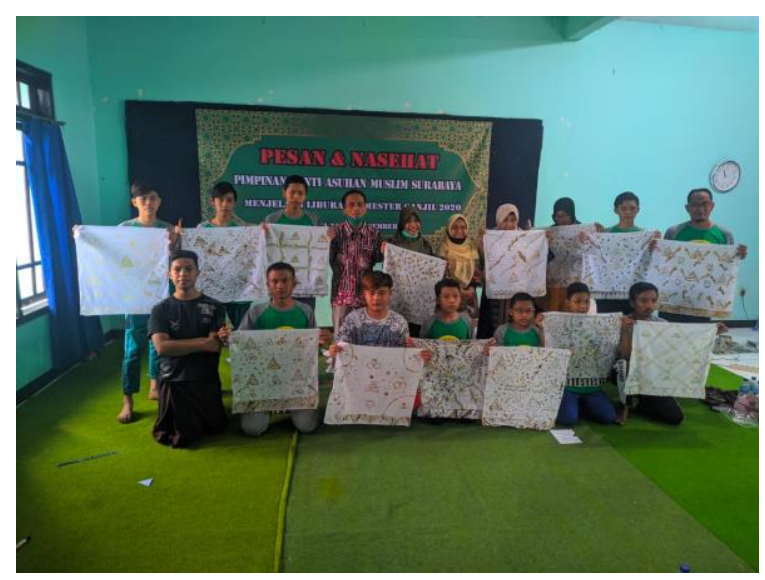

Gambar 6. Hasil pencantingan, sumber:(foto pribadi, 2020)

Tahapan kedua pada hari kedua, peserta pelatihan melakukan pewarnaan dengan media naptol dan garam. Pada proses ini dilakukan di luar aula pelatihan, hal ini dilakukan karena peratan yang digunakan yaitu kompor gas, panci dan membutuhkan air yang banyak. Proses pewarnaan peserta mendapatkan pengetahuan tentang pewarna naptol dan garam, jenis warna yang dihasilkan dari media naptol dan garam. Pada tahap ini warna yang digunakan yaitu warna orange dan biru yang dihasilkan dari naptol ASG dan garam orange gc dan biru b.

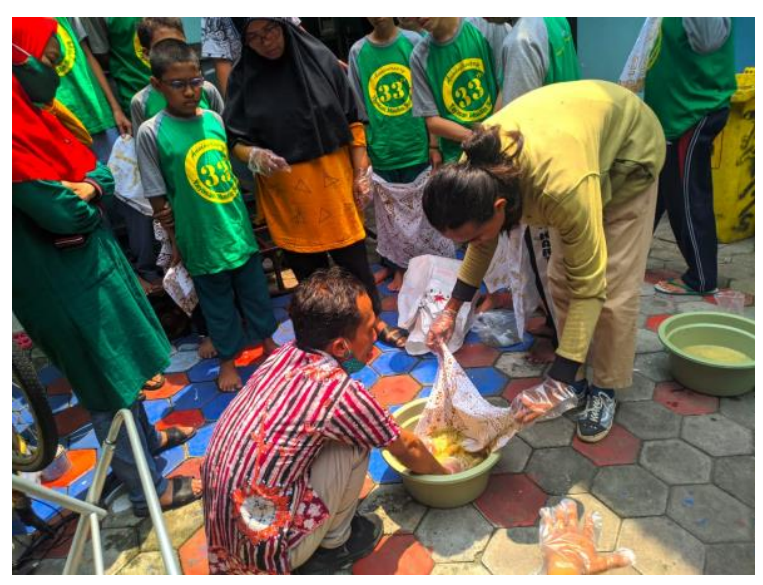

Gambar 7. Proses pewarnaan, sumber: (foto pribadi,2020)

Tahapan ketiga pada pelatihan batik tulis dihari kedua yaitu proses pelorotan, pada proses ini peserta mendapatkan pemahaman tentang tata cara dalam pelorotan batik tulis yang baik dan benar. Pada peloran ini menggunakan media fixanol pada panci pertama dan waterglass pada panci kedua. fixanol pada panci pertama berfungsi untuk bahan fiksasi atau penguat dan pengunci warna, sehingga warna tidak menglami pemudaran, sedangkan pada panci kedua yaitu larutan waterglass untuk meghilangkan malam pada kain. Pada tahapan ini dilakukan dalam kondisi air yang mendidih, guna mempercepat proses pelorotan. Pada tahapan ketiga ini berjalan dengan lancar dan semua peserta dapat memahami proses 
Pelatihan Batik Tulis Dengan Media Pewarna Naptol Garam

Bagi Siswa Panti Asuhan Yayasan Muslim Surabaya

pelorotan dengan baik dan benar.

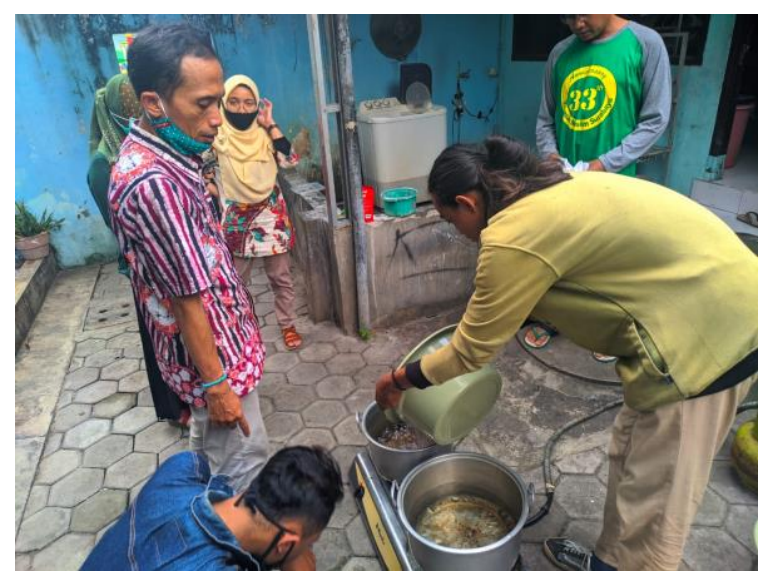

Gambar 8. Proses pelorotan, sumber:(foto pribadi, 2020)

Tahapan terakhir yaitu proses pengeringan, setelah kain di lorot makan proses pengeringan atau penjemuran dilakukan di tempat yang tidak terkena langsung oleh sinar matahari, hal ini untuk menjaga warna tetap bagus. Pada tahapan akhir ini peserta pelatihan dapan memahami dengan baik dan kegiatan ini berjalan dengan lancar.

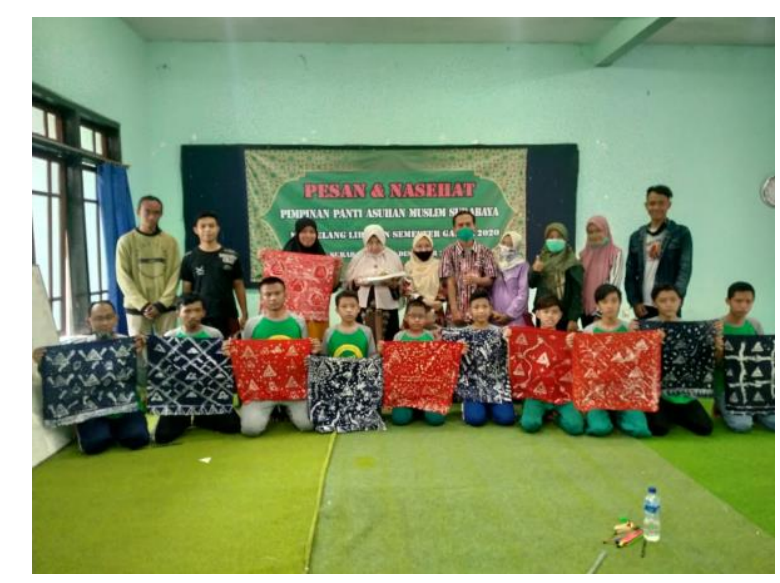

Gambar 9. Hasil akhir batik tulis motif ikon Yayasan Muslim Surabaya, sumber:(foto pribadi,2020)

\section{EVALUASI}

Pada tahapan ini wawancara dan tanya jawab kepada para peserta pelatihan untuk mendapatkan masukan yang akan dijadikan acuan kedepannya agar pelatihan dapat dilaksakan dengan baik. Pada evaluasi ini didapatkan beberapa masukan antara lain, agar penyelenggaraan pelatihan batik tulis ini dapat dilaksakan Kembali dengan media yang berbeda sehingga anak-anak panti asuhan memiliki banyak keahlian yang dapat digunakan di masyarakat. 
Pelatihan Batik Tulis Dengan Media Pewarna Naptol Garam

Bagi Siswa Panti Asuhan Yayasan Muslim Surabaya

\section{HASIL PELATIHAN}

Hasil pelatihan yang telah dilaksanakan memberikan wawasan dan ilmu baru terhadap anak-anak panti asuhan Yayasan Muslim Surabaya. Hal ini terbukti dari antusiasme dan tingkat partisipasi yang cukup tinggi selama pelatihan. Anak-anak panti asuhan telah memahami semua proses pembuatan batik tulis dengan baik dan benar, dimana ilmu yang didapat ini dapat dimanfaatkan kelak disaat mereka sudah keluar dari panti asuhan dan terjun langsung di masyarakat. Pada pelatihan ini peserta juga diberikan waktu yang luas untuk terus konsultasi jika terjadi permasalahan dalam proses pembuatan batik tulis, dan juga memberikan rekomendasi tempat jenis-jenis bahan yang dibutuhkan.

\section{KESIMPULAN}

Dari pengamatan yang dilakukan penulis, hal-hal yang sangat penting untuk diterapkan kedalam lingkungan panti asuhan terutama-anak-anak yang berada di dalamnya yaitu memberikan mereka keahlian dan keterampilan yang tepat guna, sehingga disaat mereka sudah lulus atau keluar dari panti asuhan mereka sudah siap terjun dilingkungannya masing-masing dengan keterampilan dan skill yang dimilikinya, bahkan diharapkan mereka dapat mencitkan peluang kerja buat masyarakat setempat.

Saran bagi program kegiatan berikutnya adalah dapat dilakukan kegiatan dengan menggunakan media pewarna yag ramah lingkungan seperti pewarna alam, guna menciptakan lingkungan yang ramah dan kegiatan usaha yang tidak merusak lingkungan hidup. Ditambah juga dengan pelatihan pemasaran dari produk yang telah dihasilkan agar mereka dapat mengembangkan usaha batik tulisnya. 
Pelatihan Batik Tulis Dengan Media Pewarna Naptol Garam

Bagi Siswa Panti Asuhan Yayasan Muslim Surabaya

\section{DAFTAR PUSTAKA}

Darnawi. (2011). Pengaruh Konsep Bauran Pemasaran terhadap Kepuasan Konsumen dan Keputusan Membeli Produk Batik di Malioboro. Tesis: Program Pasca Sarjana, Sekolah Tinggi Ilmu Ekonomi Pariwisata Indonesia.

Hamzuri. (1989). Batik Klasik (Classical Batik). Jakarta: Djambatan.

Purwaningtyas,N.E.,Widiarto,T.,dan Purwiyastuti,W.( 2014). Potensi Batik Bakaran Dalam Pengembangan Pariwisata di Kabupaten Pati. Universitas Kristen Satya Wacana Salatiga.

Kamil, M. (2003). Model-model pelatihan. Bandung: Universitas Pendidikan Indonesia.

Marlinah, L. (2017). Meningkatkan Ketahanan Ekonomi Nasional Melalui Pengembangan Ekonomi Kreatif. Cakrawala-Jurnal Humaniora, 17(2),258-265.

Soegijono, M. S., \& KR, D. (1993).Wawancara sebagai Salah Satu Metode Pengumpulan Data. Media Penelitian Dan Pengembangan Kesehatan, 3(1).

Trisnawati, A. E., Wahyono, H., \& Wardoyo, C. (2018). Pengembangan desa wisata dan pemberdayaan masyarakat berbasis potensi lokal. Jurnal Pendidikan: Teori, Penelitian, Dan Pengembangan, 3(1), 29-33. 